\title{
Preface
}

Despite the difficulties generated by the widespread of COVID-19, the members of the Department of Applied Mathematics of Faculty of Sciences, University of Craiova, Romania, organized, with the technical support of M. Ilie, S. Ilie, I. Murareţu, A. Popescu, S. Predoi (University of Craiova), the third edition of the International Conference on Applied Mathematics and Numerical Methods (ICAMNM 2020), see https://cis01.central.ucv.ro/ICAMNM/.

To accommodate to circumstances, this was an online event which brought together 82 researchers from 19 countries from five continents, see Figure 1.

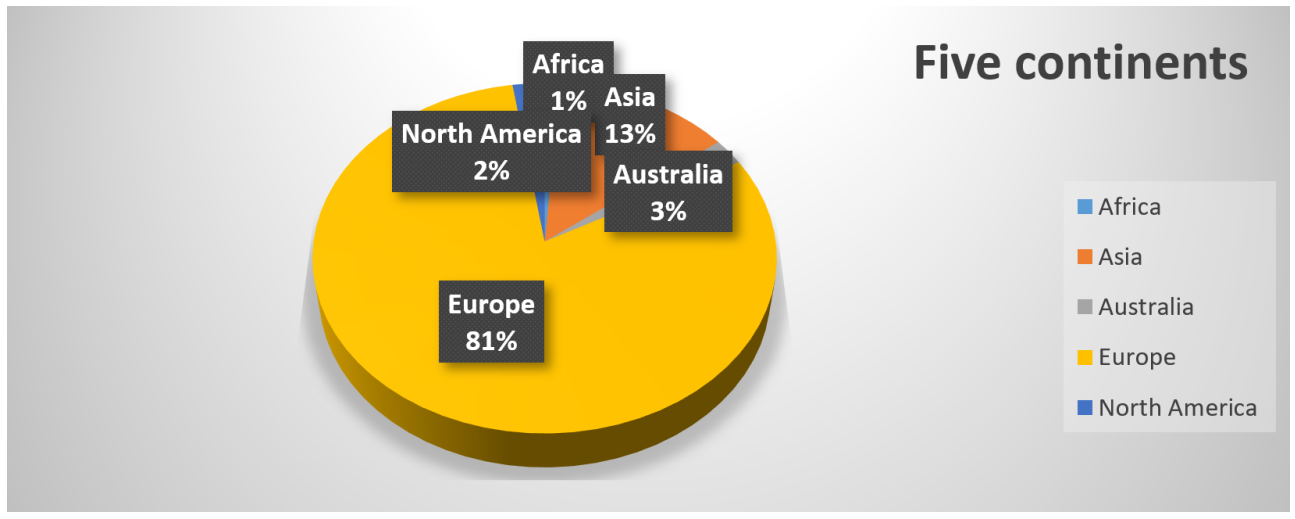

Figure 1. Five continents: Africa 1, Asia 11, Australia 2, Europe 66, North America 2.

Nineteen countries: Australia 2, Bulgaria 1, Canada 2, China 1, Ethiopia 1, France 2, India 5, Netherlands 1, Poland 1, Portugal 1, Republic of Moldova 7, Romania 48, Serbia 1, Spain 1, Thailand 1, Turkey 3, United Arab Emirates 1, United Kingdom 1, USA 2.

The scientific committee of the conference reflects this variety, too: V. BALAN (Univ. Politehnica of Bucharest, Romania), M.M. BOUREANU (Univ. Craiova, Romania), I. N. CANGÜL (Univ. Uludag, Turkey), M. CIOBAN (Univ. Tiraspol, Academy of Sciences, R. Moldova), D. CONSTANTINESCU (Univ. Craiova, Romania), S. ION ("Gheorghe MihocCaius Iacob" Institute of Mathematical Statistics and Applied Mathematics of Romanian Academy, Bucharest, Romania), M. LEFEBVRE (Polytechnique Montréal, Canada), M. MARIN (Univ. Braov, Romania), A. MATEI (Univ. Craiova, Romania), S. MICU (Univ. Craiova, Romania), M. MIHĂILESCU (Univ. Craiova, Romania), C. MOROŞANU ("Al. I. Cuza Univ.” of Iaşi, Romania), G. MOROŞANU (Babeş-Bolyai Univ., Cluj-Napoca, Romania), B. NORIS (Politecnico di Milano, Italy), M. POPESCU (Univ. Craiova, Romania), P. POPESCU (Univ. Craiova, Romania), L. RESTUCCIA (Univ. Messina, Italy), V. RĂDULESCU (Univ. Craiova, Romania), H. RAMOS CALLE (Univ. Salamanca, Spain), D. REPOVŠ (Univ. Ljubljana, Slovenia), A.M. RIBEIRO (Univ. Nova de Lisboa, Lisbon, Portugal), I. ROVENŢA (Univ. Craiova, Romania), M. SOFONEA (Univ. Perpignan, France), 
N. ThARFULEA (Purdue Univ. Northwest, Indiana, USA), A. VELEZ-SANTIAGO (Univ. Puerto Rico at Mayaguez, Puerto Rico), C. UDRIŞTE (Univ. Politehnica Bucharest, Romania), C. VLADIMIRESCU (Univ. Craiova, Romania).

The program of the conference consists of invited talks given in plenary sessions, and presentations scheduled in the following parallel sections of the conference:

- Applied Mathematics, Numerical Methods, and Geometry;

- Differential Equations, Dynamical Systems, and Their Applications.

After being subjected to a thorough peer-review process, part of the interesting presentations from ICAMNM 2020 was organized in the form of this volume of proceedings.

We truly hope that, by its content, our special number of proceedings will have a positive impact in the mathematical research community. We are looking forward to welcoming all the interested readers from mathematics, be it applied or pure, to our next edition of the conference, ICAMNM 2022.

\section{The editorial team}

Sponsors 